\title{
Os conceitos de gene e DNA por alunos ingressantes na UNIFAL-MG e a efetividade da dramatização como estratégia de ensino de Biologia Molecular
}

\author{
Gene and DNA concepts by UNIFAL-MG entering students and the effectiveness of drama as a \\ Molecular Biology teaching strategy
} \author{
Gouvêa $^{1 *}$ \\ ${ }^{1}$ Instituto de Ciências da Natureza, Universidade Federal de Alfenas - UNIFAL-MG. \\ Agência de fomento: FAPEMIG \\ "e-mail: cibelegouvea@hotmail.com
}

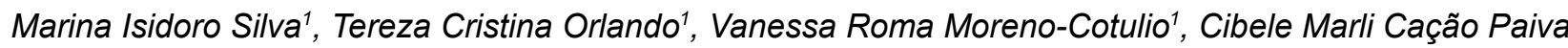

\section{Resumo}

A compreensão de conceitos de Biologia Molecular é importante para permitir o entendimento de processos biológicos, bem como para estabelecer correlações e inter-relações entre os diferentes processos celulares e a interação com o ambiente. $O$ objetivo deste trabalho foi avaliar o conhecimento dos conceitos de gene e DNA por alunos ingressantes da Universidade Federal de Alfenas-MG (UNIFAL-MG), bem como avaliar a efetividade da dramatização como estratégia inovadora de ensino. A proposta foi avaliada pela determinação do ganho de conhecimento e do desempenho escolar. Os resultados demonstraram que os alunos ingressantes na UNIFAL-MG apresentam deficiência nos conceitos de gene e composição e estrutura do DNA, provavelmente, decorrentes de falhas no processo de ensino-aprendizagem prévios ao ingresso na universidade. A dramatização apresentou-se como estratégia eficiente para induzir ganho de conhecimento e melhora do desempenho escolar de turmas com bom nível de conhecimento inicial.

Palavras-chave: Biologia Molecular, ganho de conhecimento, desempenho escolar.

\begin{abstract}
The Molecular Biology concepts comprehension is important for understanding several Biological processes as well as to establish correlations and interrelations among cell processes and its interaction with the environment. The aim of this work was to evaluate the undergraduate students from the Universidade Federal de Alfenas-MG (UNIFAL-MG) knowledge about gene and DNA concepts as well as to evaluate the effectiveness of drama as an innovative teaching strategy. This strategy was evaluated by the students' knowledge gain and scholar performance. The results showed the UNIFAL-MG beginners' students presented defective concepts about gene and DNA composition and structure, probably due to deficient teaching-learning process before the University entrance. Drama was an efficient strategy to induce learning gain and to improve scholar performance of classes with a good initial level of knowledge.
\end{abstract}

Keywords: Molecular Biology, knowledge gain, scholar performance. 
Os conceitos de gene e DNA por alunos ingressantes na UNIFAL-MG e a efetividade da dramatização como estratégia de ensino de Biologia Molecular

\section{Introdução}

A função primária de um conceito é permitir que indivíduos possam descrever situações e se comunicar efetivamente. Trata-se de ideia ou construção mental elaborada acerca de um fenômeno e inclui termos referentes aos fenômenos que ocorrem na natureza ou no pensamento. São representações cognitivas, abstratas, de uma realidade perceptível formada por experiências diretas ou indiretas e podem ser empíricas, concretas ou abstratas [1]. Como representações de uma dada realidade, os conceitos possuem atributos de caráter dinâmico, mutáveis na dimensão temporal e contextual, sendo sua evolução influenciada pelo uso e aplicação. Desse modo, para que um conceito cumpra seu papel na construção do conhecimento, é oportuno que seus atributos essenciais e, consequentemente, suas definições sejam analisados periodicamente, visando, principalmente, seu contínuo aprimoramento $[2,3]$.

Este é o caso das Ciências Biológicas, pois os inúmeros avanços científicos nesta área são acompanhados pela inserção de novos conceitos no corpo teórico da Biologia, sendo a compreensão destes, fundamental para o entendimento dos processos biológicos por alunos da Educação Básica ao Ensino Superior. Porém, a aprendizagem dos conceitos biológicos é um desafio tanto para jovens estudantes quanto para professores e pesquisadores envolvidos com a educação em ciências [3,4].

Uma das áreas de difícil compreensão para o Ensino de Biologia é a Biologia Molecular e a Genética [5], devido à complexidade dos fenômenos estudados, o que pode dificultar sua construção conceitual. A falta de integração ou fragmentação entre os temas na maioria dos livros didáticos [6,7] e a deficiência da contextualização de conteúdos [8] também dificultam o processo de ensino-aprendizagem nesta área.

Vários estudos mostram que os conceitos de Biologia Molecular e Genética são difíceis de serem trabalhados tanto no Ensino Médio como Superior [4,8], sendo que muitos alunos ao final do Ensino Médio apresentam várias concepções incorretas, sob o ponto de vista científico, sobre conceitos básicos [5,6], além de materiais didáticos com informações errôneas e desatualizadas [9].

Aprender Biologia Molecular e Genética é a base para o entendimento de questões que, hoje, estão nos mais variados meios de comunicação como, por exemplo, a importância do DNA na transmissão das características hereditárias, a descoberta e a localização de genes que predispõem à formação de determinados tumores, o uso terapêutico de células-tronco, teste de paternidade, projetos genoma, organismos transgênicos e outros. Tais conhecimentos são fundamentais para que os cidadãos sejam capazes de usar o que aprenderam ao tomar decisões de interesse individual e coletivo, 
Os conceitos de gene e DNA por alunos ingressantes na UNIFAL-MG e a efetividade da dramatização como estratégia de ensino de Biologia Molecular

considerando aspectos éticos, de responsabilidade e respeito mútuo entre os humanos e a natureza [10].

A utilização de ferramentas para tornar o processo de aprendizagem de conceitos de Biologia Molecular e Genética mais efetiva e dinâmica é importante, pois a dinamização dos meios de ensino-aprendizagem que proporcionem o envolvimento dos estudantes com práticas que fujam ao modelo bancário contribuem para o aprendizado [8].

A dramatização é uma estratégia eficiente para o ensino de adultos, pois ao assumir outros papéis, o indivíduo associa o conhecimento formal com as situações da vida real, desencadeando um processo de aprendizagem ativo e de envolvimento. Tratase de proposta educacional construtivista, que tem o aluno como agente no processo de ensino-aprendizagem, estimulando a curiosidade, a criatividade, o pensamento crítico e os diferentes estilos de aprendizagem dos alunos [11].

Neste contexto o objetivo deste trabalho foi avaliar a compreensão dos conceitos de gene e DNA por alunos ingressantes na UNIFAL-MG, bem como avaliar a efetividade da dramatização como estratégia inovadora de ensino.

\section{Metodologia}

O estudo foi conduzido após aprovação pelo Comitê de Ética em Pesquisa da UNIFAL-MG (Protocolo N. 069/2011). A primeira fase do estudo consistiu na avaliação diagnóstica, que utilizou como instrumento um questionário não-estruturado para avaliar os conhecimentos de discentes de quatro diferentes cursos de graduação da UNIFAL-MG, no início da disciplina de Biologia Molecular. O questionário constou de duas perguntas: dar o conceito de gene e descrever a composição e a estrutura do DNA. Participaram do estudo alunos dos cursos de: Ciências Biológicas, Biomedicina, Biotecnologia e Farmácia.

Foi realizada a análise de conteúdo das respostas e foram consideradas corretas as respostas que definiram gene como um segmento de DNA que é transcrito e possui sequências que regulam a transcrição e em relação à composição e estrutura do DNA, que este é composto por desoxirribonucleotídeos monofostato e apresenta as estruturas: primária (sequência de nucleotídeos), secundária (a-hélice) e terciária (dobramento espacial) [12]. A análise do conteúdo das respostas obtidas permitiu categorizá-las em 5 classes, pela escala de Likert, variando de totalmente erradas a totalmente corretas (escores de 1 a 5), o que permitiu obter os escores para cada questão. As análises foram realizadas por curso de graduação e cada curso foi dividido em dois grupos de alunos: de escolas públicas e de escolas privadas. 
Os conceitos de gene e DNA por alunos ingressantes na UNIFAL-MG e a efetividade da dramatização como estratégia de ensino de Biologia Molecular

Foi obtido o índice de dificuldade $(P)$ para cada conceito analisado, o qual mede a porcentagem de alunos que respondeu a questão corretamente e foi calculado dividindose o total de respostas corretas pelo total de respostas. Assim, baixo índice $\mathrm{P}$ indica que a questão é difícil [13].

Após avaliação diagnóstica, foram ministrados os conteúdos do programa da disciplina e foi realizada uma intervenção com alunos do curso de Ciências Biológicas, que consistiu em dramatização, utilizada como metodologia inovadora de ensino de Biologia Molecular.

A intervenção foi aplicada em 6 turmas, sendo 3 do bacharelado (1, 3 e 5) e 3 da licenciatura (2, 4 e 6). Os graduandos foram divididos em seis grupos, sendo que cada um foi acompanhado por dois integrantes do grupo do Programa de Educação Tutorial, PETBiologia e pelas professoras da disciplina. Os temas para realização da dramatização foram sorteados entre os grupos, dentre aqueles constantes no conteúdo programático da disciplina. Foram estes: replicação do DNA; mutação e reparo do DNA; transcrição e processamento de RNA; regulação da expressão gênica - sistema Operon-lac; enzimas de restrição; clonagem; PCR; teste de paternidade e identificação criminal. O preparo da dramatização foi acompanhado com reuniões mensais e antes da apresentação foi produzido o roteiro contendo todos os passos e informações, para a correção de possíveis erros conceituais relacionados aos temas. A dramatização consistiu em encenação, com tempo de apresentação de 15 a 20 min por grupo. Os alunos foram orientados a desenvolver a encenação, de forma a reforçar conceitos importantes sobre cada tema e apresentar de forma lúdica e criativa os conceitos discutidos, previamente, em aula. Após a apresentação, a satisfação dos alunos participantes foi avaliada por meio de questionário, com questões não-estruturadas e espaço para sugestões e críticas. Essa atividade foi parte da avaliação da disciplina de Biologia Molecular.

Para a verificação da eficiência da dramatização como ferramenta de ensino foram utilizadas duas avaliações processuais teóricas, com o mesmo conteúdo, aplicadas antes e depois da intervenção. As duas avaliações tiveram o mesmo valor e o mesmo peso para a aprovação dos alunos na disciplina. A comparação das notas das avaliações processuais permitiu a realização de três testes: ganho de conhecimento (g); discriminação (D) e desempenho escolar, apenas para os alunos que realizaram a dramatização e as duas avaliações processuais. O ganho de conhecimento foi calculado segundo a equação, modificada de Hake [14]:

$g(\%)=100 \times(\%$ alunos com nota $\geq 7,0$ final $-\%$ alunos com nota $\geq 7,0$ inicial $)$

(100 - \% alunos com nota $\geq 7,0$ inicial) 
Os conceitos de gene e DNA por alunos ingressantes na UNIFAL-MG e a efetividade da dramatização como estratégia de ensino de Biologia Molecular

O item discriminação (D) visou distinguir os alunos com bom desempenho daqueles com mau. Os estudantes foram divididos em 2 grupos: com nota $\geq 7,0$ e com nota $<7,0$, pois 7,0 é a nota mínima para aprovação nas disciplinas dos cursos de graduação da UNIFAL-MG. O valor $D$ fornece informação comparativa sobre $O$ desempenho dos estudantes antes e após a intervenção e foi calculado utilizando-se a fórmula modificada de Shi et al. [13]:

$$
\mathrm{D}=\frac{\text { número de notas } \geq 7,0 \text { - número de notas }<7,0}{\text { número total de alunos } / 2}
$$

O desempenho escolar da turma foi obtido pela comparação entre as médias das avaliações processuais teóricas aplicadas antes e após a dramatização e foi avaliado se a intervenção proporcionou alteração da média.

Tendo em vista que os resultados obtidos apresentaram distribuição normal, estes foram comparados por análise de variância, seguida do teste de Tukey, quando $p<0,05$ ou pelo teste $t$ de Student.

\section{Resultados e discussão}

O estudo das concepções dos alunos sobre determinado tema se expressa como um diagnóstico do processo de ensino-aprendizagem, um ponto de checagem, fornecendo informações valiosas sobre possíveis falhas nesse processo e para a adoção de medidas interventivas.

Neste trabalho foi realizada a avaliação diagnóstica para a verificação do conhecimento de alunos, ingressantes em diferentes cursos de graduação da UNIFALMG, sobre o conceito de gene e da composição e estrutura do DNA. A caracterização dos alunos participantes da primeira fase do estudo demonstrou que no curso de Biomedicina a maior parte dos alunos $(62,5 \%)$ concluiu o ensino médio em escolas públicas, enquanto na Biotecnologia a maior parte dos alunos $(63,6 \%)$ concluiu o ensino médio em escolas particulares (Tabela 1).

Tabela 1: Caracterização dos alunos participantes da avaliação diagnóstica do presente estudo, quanto à conclusão do ensino médio em escolas públicas ou privadas.

\begin{tabular}{lccc}
\hline \hline Curso de graduação & $\begin{array}{c}\text { Total de alunos } \\
\text { participantes }\end{array}$ & \multicolumn{2}{c}{ Conclusão do ensino médio (\%) } \\
\cline { 3 - 4 } & & Escola pública & Escola privada \\
\hline Ciências Biológicas & 26 & 53,8 & 46,2 \\
Biomedicina & 16 & 62,5 & 37,5 \\
Biotecnologia & 22 & 36,4 & 63,6 \\
Farmácia & 20 & 45,0 & 55,0 \\
\hline \hline
\end{tabular}


Os conceitos de gene e DNA por alunos ingressantes na UNIFAL-MG e a efetividade da dramatização como estratégia de ensino de Biologia Molecular

As respostas obtidas para os conceitos de gene e DNA estão apresentadas na Tabela 2. A análise dos dados permitiu identificar que, para a maioria dos participantes deste estudo, gene é um "pedaço" de DNA responsável pelas características individuais como cor do cabelo e dos olhos. Em relação ao DNA, as respostas foram mais variadas e conceitos errôneos tais como, ser constituído por proteínas, por ácidos nucleicos, por ácido desoxirribonucleico, possuir estrutura circular, são alguns exemplos de respostas obtidas.

Tabela 2: Análise das respostas sobre os conceitos de gene e composição e estrutura do DNA dos alunos ingressantes em diferentes cursos de graduação da UNIFAL-MG.

\begin{tabular}{|c|c|c|c|c|c|c|c|c|c|c|c|}
\hline \multirow{3}{*}{$\begin{array}{l}\text { Curso de } \\
\text { graduação }{ }^{1}\end{array}$} & \multirow{3}{*}{$\begin{array}{l}\text { Ensino } \\
\text { médio }\end{array}$} & \multicolumn{10}{|c|}{ "Escores ${ }^{2}(\%)$} \\
\hline & & \multicolumn{2}{|c|}{1} & \multicolumn{2}{|c|}{2} & \multicolumn{2}{|c|}{3} & \multicolumn{2}{|c|}{4} & \multicolumn{2}{|c|}{5} \\
\hline & & Gene & DNA & Gene & DNA & Gene & DNA & Gene & DNA & Gene & DNA \\
\hline \multirow[t]{2}{*}{ CB } & Pública & 0 & 0 & 3,85 & 11,53 & 7,70 & 7,70 & 3,84 & 7,70 & 26,92 & 15,39 \\
\hline & Privada & 0 & 0 & 3,85 & 26,92 & 19,23 & 11,53 & 15,40 & 11,53 & 19,23 & 7,70 \\
\hline \multirow[t]{2}{*}{ Biomed } & Pública & 0 & 6,25 & 6,25 & 18,75 & 37,5 & 12,5 & 0 & 0 & 0 & 6,25 \\
\hline & Privada & 0 & 0 & 12,5 & 12,5 & 37,5 & 31,25 & 0 & 12,5 & 6,25 & 0 \\
\hline \multirow[t]{2}{*}{ Biotec } & Pública & 0 & 0 & 4,54 & 0 & 4,54 & 4,54 & 0 & 0 & 4,54 & 9,10 \\
\hline & Privada & 0 & 0 & 4,54 & 22,72 & 18,2 & 31,81 & 9,10 & 18,20 & 54,54 & 13,63 \\
\hline \multirow[t]{2}{*}{ Farm } & Pública & 0 & 0 & 5,00 & 0 & 20,00 & 0 & 0 & 15,00 & 0 & 10,00 \\
\hline & Privada & 0 & 0 & 5,00 & 30,0 & 70,00 & 5,00 & 0 & 20,00 & 0 & 20,00 \\
\hline
\end{tabular}

$1 \overline{\mathrm{CB}}$, Ciências Biológicas; Biomed, Biomedicina; Biotec, Biotecnologia, Farm, Farmácia; ${ }^{2}$ As respostas foram categorizadas em 5 classes (escala de Likert), sendo 1 para a resposta totalmente errada e 5 para a resposta totalmente correta.

As investigações em Ensino de Ciências evidenciam que durante o processo de ensino-aprendizagem, um conceito já existente, ainda que falso em um plano científico, serve de sistema explicativo eficaz e funcional para o estudante [15]. Assim, a aprendizagem significativa somente ocorre quando novos significados são adquiridos, por meio de um processo de interação de novas ideias com conceitos relevantes já existentes na sua estrutura cognitiva. Pedrancini et al. [7] ao estudarem a apropriação do saber científico e biotecnológico entre alunos do Ensino Médio, observaram que os alunos se apropriaram de termos e expressões isoladas muitas vezes veiculadas pelos meios de comunicação, porém, quando são estimulados a explicá-los, percebe-se que não se apropriaram dos conceitos científicos envolvidos. Dessa forma, a falta de conhecimento de conceitos, como de gene e DNA observados nesse trabalho, pode dificultar o estabelecimento de conexões futuras com outros temas de Biologia Molecular e Genética.

De acordo com a Tabela 2, a maioria dos alunos obteve escores 2 e 3 para os conceitos de gene, composição e estrutura do DNA analisados, demonstrando que não conhecem os conceitos corretos de gene e composição e estrutura do DNA. Observa-se que para o conceito de gene, os alunos que obtiveram o maior escore foram de Biotecnologia, seguidos pelos alunos de Biologia e Biomedicina respectivamente. Para o conceito de composição e estrutura do DNA os alunos de Farmácia, Biologia, 
Os conceitos de gene e DNA por alunos ingressantes na UNIFAL-MG e a efetividade da dramatização como estratégia de ensino de Biologia Molecular

Biotecnologia e Biomedicina, respectivamente obtiveram os maiores escores. Comparando-se os maiores escores obtidos para os dois conceitos em conjunto, observase que a Biotecnologia apresentou a maior porcentagem de alunos com escore máximo, seguida da Biologia, Farmácia e Biomedicina. É interessante salientar que a maior parte dos alunos do curso de Biotecnologia concluiu o ensino médio em escolas privadas, enquanto no curso de Biomedicina a maioria concluiu em escolas públicas. Assim, os resultados do presente trabalho demonstram desigualdade de conhecimento entre os alunos dos diferentes cursos de graduação analisados, bem como entre os provenientes de escolas públicas e privadas.

Em estudo diagnóstico sobre o conhecimento de conceitos de alunos de cursos introdutórios de Biologia Molecular e Biologia Celular de três diferentes instituições, Shi et al. [13] obtiveram níveis similares de conhecimento e compreensão de conceitos. Uma possível explicação para o resultado divergente do presente trabalho pode ser a desigualdade no ensino médio observado em nosso país. Segundo o Instituto Nacional de Estudos e Pesquisas Educacionais Anísio Teixeira [16], que avalia o desempenho de estudantes do ensino médio por meio de indicadores disponibilizados pelo Sistema Nacional de Avaliação da Educação Básica, os alunos de escolas públicas são os que possuem os piores índices. Entre os $42 \%$ dos alunos qualificados como 'muito crítico', $96 \%$ são de escolas públicas. De acordo com outros estudos, essa defasagem dos alunos de escolas públicas em relação aos de escola privada pode ser influenciada pela falta de infraestrutura adequada dos estabelecimentos escolares, a falta de laboratórios, a qualidade dos professores, além de aspectos familiares, como renda, nível de escolaridade dos pais, acesso à internet e outras fontes de informações [17]. Desde meados da década de 1990, o ensino médio público brasileiro tem se expandido. No entanto, observam-se ainda altas porcentagens de jovens que permanecem fora da escola, a tendência ao declínio do número de matrículas desde 2004 e a persistência de altos índices de evasão e reprovação, que enfatizam a desigualdade regional quanto ao acesso e universalização do ensino [18]. Além disso, os docentes do ensino médio, embora já não sejam idealizados pelos alunos assim como eram os professores do ensino fundamental, continuam representando uma referência muito importante quanto à motivação para os alunos [19].

É provável que, pelo menos parte dos resultados obtidos para o conhecimento dos conceitos de gene e DNA apresentados pelos alunos, possam ser atribuídos à falta de atualização de conhecimentos, informações e conceitos pelos professores de Ensino Médio, uma vez que muitos destes não tiveram a disciplina de Biologia Molecular no curso 
Os conceitos de gene e DNA por alunos ingressantes na UNIFAL-MG e a efetividade da dramatização como estratégia de ensino de Biologia Molecular

de graduação [4]. A falta de conhecimento de conceitos básicos, como observado no presente trabalho, pode prejudicar a conexão com processos complexos, impossibilitando a criação de uma rede sólida de conhecimento [20] e até mesmo de atingir vários dos objetivos preconizados pelo ensino de Biologia, tais como contribuir para que os cidadãos sejam capazes de: compreender conceitos e processos biológicos; visualizar a importância da ciência e da tecnologia; usar o que aprenderam ao tomar decisões de interesse individual e coletivo, no contexto de um quadro ético de responsabilidade e respeito que leva em conta o papel do homem na biosfera e ampliar o entendimento que o indivíduo tem da sua própria organização biológica e do lugar que ocupa na natureza e na sociedade, visando à melhoria da qualidade de vida [21,22].

Com os resultados obtidos, descritos na Tabela 2, foi possível o cálculo do índice de dificuldade $(P)$ para os conceitos analisados, produzindo-se a Tabela 3. O baixo índice $P$ indica que a questão é difícil e os alunos do curso de Biomedicina obtiveram os menores índices, indicando que são os alunos com maior dificuldade.

Tabela 3: Índice de dificuldade $(\mathrm{P})$ de graduandos de diferentes cursos da UNIFAL-MG sobre os conceitos de gene e composição e estrutura do DNA.

\begin{tabular}{llll}
\hline \hline Curso $^{1}$ & Ensino Médio & \multicolumn{2}{c}{$\mathrm{P}$} \\
\cline { 3 - 4 } & & Gene & DNA \\
\hline CB & Pública & 0,27 & 0,15 \\
\multirow{2}{*}{ Biomed } & Privada & 0,19 & 0,08 \\
& Pública & 0 & 0,06 \\
Biotec & Privada & 0,06 & 0 \\
& Pública & 0,45 & 0,09 \\
Farm & Privada & 0,55 & 0,14 \\
& Pública & 0 & 0,10 \\
& Privada & 0 & 0,20 \\
\hline \hline
\end{tabular}

${ }^{1} \mathrm{CB}$, Ciências Biológicas; Biomed, Biomedicina; Biotec, Biotecnologia, Farm, Farmácia.

Após identificar que os alunos participantes do estudo apresentavam deficiência de conhecimento de conceitos básicos de Biologia Molecular, foi realizada intervenção por meio da dramatização, que foi aplicada para alunos de 6 diferentes turmas de apenas um curso de graduação, para avaliar a ferramenta de ensino antes de sua ampla utilização. $O$ curso de Ciências Biológicas foi o escolhido por ser o de origem do grupo PET-Biologia e as ações de ensino dos grupos PET devem ser voltadas, prioritariamente, para o curso de graduação ao qual o grupo está vinculado [22].

A análise do ganho de conhecimento (g) (Tabela 4) demonstrou que para as turmas $1,3,4$ e 5 houve ganho de conhecimento, enquanto para as turmas 2 e 6 não houve. $A$ turma 1 apresentou o maior índice g e a turma 2 apresentou o menor. $O$ índice $g$ foi significativamente $(p<0,05)$ diferente para as diferentes turmas analisadas. 
Os conceitos de gene e DNA por alunos ingressantes na UNIFAL-MG e a efetividade da dramatização como estratégia de ensino de Biologia Molecular

Tabela 4. Análise do ganho de conhecimento (g) para alunos do curso de Ciências Biológicas da UNIFALMG, após a aplicação de dramatização, como estratégia de ensino. Valor positivo de g indica ganho de conhecimento.

\begin{tabular}{rccr}
\hline \hline Turma & $\begin{array}{c}\text { Nota } \geq 7,0 \\
\text { inicial }(\%)\end{array}$ & $\begin{array}{c}\text { Nota } \geq 7,0 \\
\text { final }(\%)\end{array}$ & $\mathrm{g} \mathrm{( \% )}$ \\
\hline 1 & 69,04 & 92,86 & $76,94^{\mathrm{a}}$ \\
2 & 70,27 & 48,65 & $-72,72^{\mathrm{b}}$ \\
3 & 67,64 & 82,24 & $45,12^{\mathrm{c}}$ \\
4 & 39,40 & 69,70 & $50,00^{\mathrm{c}}$ \\
5 & 21,42 & 28,57 & $9,10^{\mathrm{d}}$ \\
6 & 42,86 & 21,43 & $-37,50^{\mathrm{e}}$ \\
\hline
\end{tabular}

Letras diferentes na mesma coluna indicam diferença estatisticamente significativa $(p<0,05)$ pelo teste $t$ Student.

No presente trabalho o ganho de conhecimento foi avaliado com base nas notas das avaliações realizadas antes e depois da intervenção, uma vez que Shi et al. [13] obtiveram resultados diferentes para as mesmas questões quando estas foram integrantes da prova e quando foram aplicadas em questionários não integrantes de sistema de avaliação. Os autores sugerem que a avaliação do ganho de conhecimento seja feita avaliando-se as respostas dadas em provas, pois a qualidade das respostas é afetada pelo tempo gasto para responder e pela motivação dos alunos. Em uma situação de prova os alunos são motivados a mostrar o seu melhor, enquanto na avaliação não integrante de sistemas que ofereçam recompensa imediata para os alunos, estes respondem as questões ao acaso, gastam pouco tempo e não se empenham para responder da forma mais correta possível.

Os resultados indicam que a dramatização pode contribuir para o processo de ensino-aprendizagem, apresentando-se como uma ferramenta apropriada para a obtenção de aprendizagem significativa, já que houve ganho de conhecimento. A assimilação de conhecimentos ocorre sempre que uma nova informação interage com outra existente na estrutura cognitiva, sendo que o processo contínuo de aprendizagem significativa acontece apenas com a integração de conceitos relevantes, por meio de uma relação não arbitrária e substantiva [23].

A dramatização não proporcionou ganho de conhecimento para todas as turmas analisadas, contudo, neste trabalho não foi possível identificar as causas para o insucesso obtido nas turmas 2 e 6 , mas este não pode ser totalmente atribuído às desigualdades do ensino médio, uma vez que a turma 2 ingressou por vestibular, enquanto a turma 6 pelo Sistema de Seleção Unificada (SiSU). A falta de motivação da turma pode ter contribuído para o resultado obtido.

Os resultados da Tabela 5 corroboram os dados para o ganho de conhecimento observado nas turmas 1,3 e 4, pois houve aumento do índice $D$, indicando melhora do desempenho, enquanto isso não ocorreu nas turmas 2,5 e 6 . $O$ índice $D$ permitiu 
Os conceitos de gene e DNA por alunos ingressantes na UNIFAL-MG e a efetividade da dramatização como estratégia de ensino de Biologia Molecular

identificar na turma 5, que apesar de apresentarem ganho de conhecimento, este não foi homogêneo, uma vez que o índice $D$ diminuiu, o que permitiu discriminar que a turma é heterogênea, com alunos com bom e mau desempenho. Este resultado não seria obtido apenas pela análise do índice $\mathrm{g}$. Sendo assim, pode-se inferir que a intervenção não contribuiu para o ganho de conhecimento de forma homogênea.

Tabela 5. Discriminação (D) entre estudantes com melhor e pior desempenhos. A diminuição do valor D significa que houve piora no desempenho.

\begin{tabular}{crr}
\hline \hline Turma & \multicolumn{2}{c}{$\mathrm{D}$} \\
\cline { 2 - 3 } & Inicial & Final \\
\hline 1 & $0,76^{\mathrm{a}}$ & $1,71^{\mathrm{e}}$ \\
2 & $0,81^{\mathrm{a}}$ & $-0,05^{\mathrm{f}}$ \\
3 & $0,71^{\mathrm{a}}$ & $1,53^{\mathrm{e}}$ \\
4 & $0,42^{\mathrm{b}}$ & $0,79^{\mathrm{a}}$ \\
5 & $1,14^{\mathrm{c}}$ & $-0,85^{\mathrm{a}}$ \\
6 & $-0,28^{\mathrm{d}}$ & $-1,14^{\mathrm{h}}$ \\
\hline \hline
\end{tabular}

Letras diferentes na mesma linha ou coluna indicam diferença estatisticamente significativa $(p<0,05)$ pelo teste $t$ de Student.

A avaliação do desempenho escolar (Tabela 6) permitiu observar que as turmas 1 , 3 e 4 conseguiram melhores notas após a intervenção. O mesmo não ocorreu com as demais, indicando que para as turmas 1, 3 e 4 a intervenção foi positiva e para as demais turmas não produziu efeito na melhora do desempenho escolar.

Foi possível observar diferença significativa entre as médias iniciais das diferentes turmas, o que demonstra conhecimento heterogêneo. Isto também pode ter contribuído para o resultado inconsistente de ganho de conhecimento com a dramatização, pois a deficiência de conhecimento prévio faz com que os alunos tenham que se dedicar muito aos estudos para que os conhecimentos da turma se tornem homogêneos, o que pode desmotivar os alunos com baixo desempenho inicial.

Tabela 6. Desempenho escolar, avaliado pelas médias das notas das avaliações teóricas aplicadas antes (inicial) e depois (final) da dramatização. Valor final maior que o inicial indica melhora do desempenho escolar.

\begin{tabular}{ccc}
\hline \hline Turma & \multicolumn{2}{c}{ Média } \\
\cline { 2 - 3 } & Inicial & Final \\
\hline 1 & $7,84 \pm 0,22^{\mathrm{a}^{*}}$ & $8,61 \pm 0,16^{\mathrm{a}^{* *}}$ \\
2 & $7,72 \pm 0,29^{\mathrm{a}^{*}}$ & $7,07 \pm 0,26^{\mathrm{b}^{*}}$ \\
3 & $7,52 \pm 0,28^{\mathrm{a}^{*}}$ & $8,79 \pm 0,23^{\mathrm{a}^{* *}}$ \\
4 & $6,38 \pm 0,34^{\mathrm{b}^{*}}$ & $7,53 \pm 0,31^{\mathrm{b}^{* *}}$ \\
5 & $5,77 \pm 0,43^{\mathrm{b}^{*}}$ & $6,23 \pm 0,27^{\mathrm{d}^{*}}$ \\
6 & $6,55 \pm 0,59^{\mathrm{b}^{*}}$ & $6,02 \pm 0,44^{\mathrm{d}^{*}}$ \\
\hline \hline
\end{tabular}

Diferentes letras na mesma coluna e asterisco na mesma linha indicam diferença estatisticamente significativa $(p<0,05)$ pelo teste de Tukey.

A análise conjunta dos dados do presente trabalho indica que a dramatização apresenta-se com uma metodologia interessante para auxiliar na compreensão de 
Os conceitos de gene e DNA por alunos ingressantes na UNIFAL-MG e a efetividade da dramatização como estratégia de ensino de Biologia Molecular

conceitos básicos e no ganho de conhecimento de Biologia Molecular, pois envolve o plano da realidade, no qual os alunos expressam o que sabem ou sentem em relação ao tema e tem como objetivo estimular a análise; o plano simbólico, com a elaboração conceitual do conteúdo proposto e a expressão do que os alunos compreenderam sobre o tema, estimulando a capacidade de síntese e o plano da fantasia, com a apresentação do tema em uma situação adaptada ou criada pelos alunos, partindo do conhecimento prévio e do adquirido, o que equivale à generalização resultante das soluções próprias dos alunos [11]. Estes planos foram plenamente alcançados neste trabalho, pois houve a adesão dos alunos à proposta e estes se dedicaram a estudar o tema do seu grupo. Todo o roteiro do teatro foi proposto e adaptado pelos alunos. Houve intervenção docente apenas para dirimir dúvidas e corrigir eventuais informações incorretas. As composições psicodramáticas utilizadas incluíram jornal vivo, sociodrama, vídeos musicais, representação de tribunal, simulação de aulas práticas em laboratório, além de releituras de obras clássicas.

É interessante ressaltar que a análise qualitativa das opiniões dos alunos que atuaram na dramatização, revelou que a maioria: considera que a dramatização ajudou na compreensão do conteúdo abordado por seu próprio grupo e pelos demais grupos; percebeu alteração positiva no seu desempenho, motivação para o aprendizado e interesse pela disciplina; observou melhora na interação e no relacionamento com os colegas de classe, além da ampliação dos conhecimentos extraclasse. Assim, foi evidenciado, que atividades lúdicas não só auxiliam no aprendizado em sala de aula, mas também em outros aspectos da vida dos alunos. A interação social, segundo Vigotski [24], é um elemento essencial na construção do conhecimento, pois permite que ocorra troca de experiências, característica marcante da dramatização, que se configura como um processo dialético e dialógico que relaciona os sujeitos da ação com o meio em que estão inseridos [25].

Apesar dos indícios da efetividade da dramatização no processo de ensino aprendizagem, apresentados nesse trabalho, os resultados indicam que esta estratégia não consegue atingir todos os alunos de uma mesma turma, principalmente, quando há alunos com níveis de conhecimento heterogêneos e conhecimento inicial precário. Assim, sugere-se a utilização da dramatização para turmas que apresentam bom nível de conhecimento inicial e para as que não apresentam, recomenda-se a utilização de outras metodologias de ensino. Trabalhos estão em progresso em nosso grupo para avaliação de outros tipos de intervenção com alunos da UNIFAL-MG. 
Os conceitos de gene e DNA por alunos ingressantes na UNIFAL-MG e a efetividade da dramatização como estratégia de ensino de Biologia Molecular

\section{Conclusão}

Os dados do presente trabalho permitem concluir que os alunos ingressantes na UNIFAL-MG apresentaram deficiência no conhecimento de conceitos de gene e composição e estrutura do DNA, provavelmente, decorrentes de falhas no processo de ensino-aprendizagem prévio ao ingresso na universidade. A dramatização foi utilizada como forma auxiliar do processo de ensino-aprendizagem de Biologia Molecular, pois se trata de estratégia construtivista, na qual o aluno tem importante papel, estimulando sua criatividade, espontaneidade e as relações sociais, o que leva ao crescimento intelectual e pessoal, induzindo o ganho de conhecimento e a melhora do desempenho escolar de turmas com bom nível de conhecimento inicial.

\section{Referências}

[1] Fernandes MGM, Nóbrega MML, Garcia TR, Macêdo-Costa KNF. Análise conceitual: considerações metodológicas. Rev Bras Enferm 2011; 64 (6): 1150-1156.

[2] Joaquim LM, El-Hani CN. A genética em transformação: crise e revisão do conceito de gene. Sci Stud 2010; 8(1): 93-128.

[3] Schneider EM, Justina LAD, Andrade MABS, Oliveira TB, Caldeira AMA, Meglhioratti FA. Conceitos de gene: construção histórico-epistemológica e percepções de professores do ensino superior. IENCI 2011; 16(2): 201-222.

[4] Camargo SS, Infante-Malachias ME, Amabis JM. O ensino de Biologia Molecular em faculdades e escolas médias de São Paulo. RBEBBM 2007; 5(1): 1-14.

[5] Klautau-Guimarães N, Aurora A, Dulce D, Silviene S, Helena H, Correia A. Relação entre herança genética, reprodução e meiose: um estudo das concepções de estudantes universitários do Brasil e Portugal. In Anais do VIII Congreso Internacional sobre Investigación en Didáctica de lãs Ciencias, Barcelona, Enseñanza de las Ciencias, Número Extra, 2009. p. 2267-2270. Acesso em 12 de Fevereiro de 2014. Disponível em: http://ensciencias.uab.es/congreso09/numeroextra/art-2267-2270.pdf.

[6] Paiva, A. L. B.; Martins, C. M. C. Concepções prévias de alunos de terceiro ano do Ensino Médio a respeito de temas na área de Genética. Ensaio 2005; 7(3). Acesso em 08 de Abril de 2014 Disponível em: http://www.portal.fae.ufmg.br/seer/index.php/ensaio/article/view/99/148.

[7] Pedrancini VD, Corazza-Nunes MJ, Galuch MTB, Moreira ALOR, Ribeiro AC. Ensino e aprendizagem de Biologia no ensino médio e a apropriação do saber científico e biotecnológico. REEC 2007; 6(2): 299-309.

[8] Melo JR, Carmo EM. Investigações sobre o ensino de Genética e Biologia Molecular no Ensino Médio brasileiro: reflexões sobre as publicações científicas. Ciênc Educ 2009;15(3): 592-611.

[9] Vilas-Boas, A. Conceitos errôneos de Genética em livros didáticos do ensino médio. RGE 2006; 1(1): 9-11. 
Os conceitos de gene e DNA por alunos ingressantes na UNIFAL-MG e a efetividade da dramatização como estratégia de ensino de Biologia Molecular

[10] Brasil. Orientações curriculares para o ensino médio: Ciências da natureza, matemática e suas tecnologias. v. 2. Brasília: Ministério da Educação, Secretaria de Educação Básica, 2006. 135 p.

[11] Unalan PC, Uzuner A, Cifçili S, Akman M, Hancioğlu S, Thulesius HO. Using theatre in education in a traditional lecture oriented medical curriculum.BMC Med Educ, 2009; 9: 73.

[12] Griffiths AJF, Wessler SR, Carroll SB, Doebley J. Introdução à Genética. 10. Ed. Rio de Janeiro: Guanabara, 2013.

[13] Shi J, Wood WB, Martin JM, Guild NA, Vicens Q, Knight JK. A diagnostic assessment for introductory Molecular and Cell Biology. CBE Life Sci Educ 2010; 9(4):453-461.

[14] Hake RR. Interactive-engagement versus traditional methods: a six-thousand-student survey of mechanics test data for introductory physics courses. Am J Physics1998; 66(1): 64-74.

[15] Astolfi JP, Develay M. A didática das Ciências. 12 ed. Campinas: Papirus, 1990.

[16] INEP - Instituto Nacional de Estudos e Pesquisas Educacionais Anísio Teixeira. Relatório Nacional PISA 2012 - Resultados Brasileiros. Acesso em 17 de Maio de 2014. Disponivel

e $\mathrm{m}$ : http://download.inep.gov.br/acoes_internacionais/pisa/resultados/2014/relatorio_nacional_ PISA_2012_resultados_brasileiros.pdf.

[17] Sampaio B, Guimarães J. Diferenças de eficiência entre ensino público e privado no Brasil. Econ Apl 2009; 13(1):45-68.

[18] Krawczyk, N. Reflexão sobre alguns desafios do ensino médio no Brasil hoje. Cad Pesq 2011; 41(144): 752-769.

[19] Santos Del Real A. La Educación secundaria: perspectivas de su demanda. Tese de Doutorado [Educação] - Universidad Autónoma de Aguascalientes. 2000.

[20] Novak JD. Meaningful learning: the essential factor for conceptual change in limited or inappropriate propositional hierarchies leading to empowerment of learners. Sci Edu 2002; 86(4): 548-571.

[21] Krasilchik M. Prática de ensino de biologia. 4. ed. São Paulo: Edusp, 2004.

[22] Brasil. Ministério da Educação. Programa de educação tutorial - PET: Manual de orientações básicas. Brasília: Ministério da Educação, 2006.

[23] Ausubel DP, Novak JD, Hanesian H. Psicologia educacional. 2. ed. Rio de Janeiro: Interamericana, 1980.

[24] Vygotsky LS. A formação social da mente. São Paulo: Martins Fontes, 2000.

[25] Silveira AF, Ataíde ARP, Freire MLF. Atividades lúdicas no ensino de ciências: uma adaptação metodológica através do teatro para comunicar a ciência a todos. Educ Rev 2009; (34): 251-262.

\section{Agradecimentos}

Ao PET-MEC-SeSU pela concessão de bolsa para M. I. Silva e C. M. C. P. Gouvêa e à FAPEMIG pelo auxílio financeiro (APQ-03227-12). 